European journal of American studies

4-1 | 2009

Spring 2009

\title{
THE MUMMY in context
}

\section{Richard Freeman}

\section{(2) OpenEdition}

\section{Journals}

Electronic version

URL: https://journals.openedition.org/ejas/7566

DOI: 10.4000/ejas.7566

ISSN: 1991-9336

\section{Publisher}

European Association for American Studies

\section{Electronic reference}

Richard Freeman, "THE MUMMY in context", European journal of American studies [Online], 4-1 | 2009, document 4, Online since 04 June 2009, connection on 08 July 2021. URL: http://

journals.openedition.org/ejas/7566 ; DOI: https://doi.org/10.4000/ejas.7566

This text was automatically generated on 8 July 2021.

Creative Commons License 


\title{
THE MUMMY in context
}

\author{
Richard Freeman
}

1 One reason why mummy films suffer in comparison to other films of the classic horror genre is that they have, as Kim Newman describes it, no "foundation text" (Newman 225). The other famous monsters either have a literary source beginning with Frankenstein by Mary Shelley, and ending with Leroux's Phantom of the Opera in 1911, or they have a mythical origin such as the vampire or werewolf.

Mythology regarding re-animated mummies is also a nineteenth-century invention. There are no records in archaeology that the ancient Egyptians ever considered such a possibility. The mummified body was for use in the after-life, not for re-use on this earth; it served as the link between the physical self and the $k a$, the spirit. Due to the mummification process, it was also unlikely that a re-animated mummy would be able to function. This was because the process involved the removal of vital organs, including the brain and the eyes, the loss of which would have made a revived mummy somewhat ineffective. In the Universal horror films, and the Hammer remake in 1959, the mummy is buried alive, this punishment making the removal of vital organs unnecessary. The idea of being buried alive appears in Cleopatra (1889), a novel by H. Rider Haggard. In this story a high priest called Harmachis, the main protagonist of the story, is buried alive by his priests for failing to remain pure to Isis (Pearson 230). This thread, of offending the ancient gods, is one of many that have found their way, consciously or unconsciously, into the scripts of the films.

3 The first story in the English language to feature a revived mummy was published in 1827, written by Jane Webb, called The Mummy! A Tale of the Twenty-Second Century. It shares with Frankenstein the theme of a re-animated being, but rather than being brought to life by chemical means as Mary Shelley had employed, here it is through electricity, an idea that the filmmakers would adopt for the Frankenstein story. Other than a revived mummy, this novel has no other connection with films, nor does Edgar Allan Poe's Some Words with a Mummy, 1845, which also revives a mummy through electricity. In 1858 Théophile Gautier published The Romance of the Mummy, which is historically accurate about Egypt, and also introduces the idea of love across the ages. An ancient Queen's remains are transported to England by an archaeologist, who has 
read the sad tale of her life, and he falls in love with the memory of her. In 1863 Gautier wrote The Mummy's Foot, which is the first with supernatural overtones. After buying the preserved foot of an Egyptian princess to use as a paperweight, the narrator dreams that the princess comes to reclaim her lost appendage. She and he then travel back to ancient Egypt where her father denies them permission to marry as the storyteller does "not know how to preserve" himself. Again the mummy here was not a threatening force, or a role model for future films (Craig and Smith 174). In his Smith and the Pharaohs, Haggard uses a similar device, when an Egyptologist is locked in the Cairo Museum overnight. He apparently dreams that the ancient Kings and Queens of Egypt come to life to discuss the desecration of their tombs. In his 1897 novel The Beetle, Richard Marsh introduced the theme of vengeance for defiling a tomb. In this story a fantastical creature from Egypt, "born neither of God nor man," with supernatural and hypnotic powers (like Karloff in the 1932 film), stalks a British politician who had earlier opened a sacred tomb. However, apart from this and the reincarnation theme introduced by Haggard, it was Arthur Conan Doyle who introduced most of the recognizable plot points from the Hollywood movies in his two stories The Ring of Thoth (1890) and Lot No. 249 (1892).

The first story concerns scientist John Vansittart Smith and his encounter with an attendant in the Louvre, an Egyptian called Sosra, who claims to have been born 1600 years before Christ (Craig and Smith 174). Sosra discovered a chemical compound that has made him immune to disease and death. Later in the story Sosra, secretly observed by Smith, enters one of the rooms and takes a mummy from a case. Elsewhere Sosra describes a scene that is shown directly in the 1932 film: "In a frenzy I broke my way through the attendants, and rushed through hall and corridor to my Atma's chamber. She lay upon her couch, her head high upon the pillow, with a pallid face and glazed eye." This same scene is used again in two of the Universal B pictures of the 1940s, substituting different actors for the close-ups. The mummy that Sosra took from the case was that of the woman he loved in ancient Egypt. He has continued to be in love with her over the centuries, and this is central to the plot of The Mummy (Dir: Karl Freund, 1932) and the other films discussed here.

5 His other story, Lot No. 249, is less influential, but does include three important elements. Firstly, there is the notion of the avenging mummy, which is the popular conception of the "monster." That the mummy is being controlled by someone else is used in the Universal pictures of the 1940s and in the Hammer film of 1959. Secondly, there is the (unexplained) use of a scroll, which may have been used in bringing the mummy to life. Universal, and in particular screenwriter John Balderston, created the Scroll of Thoth, central to the revival of Boris Karloff's Im-Ho-Tep. Thirdly, there is also mention made of strange leaves, which may be the origin of the tana leaves, which were used in the 1940s films to keep the mummy alive (Delahoyde 1).

6 The one novel dealing with a mummy that has been filmed is Stoker's Jewel of the Seven Stars. However, no aspects of this work found their way into the films of Universal, especially as it does not include a revived mummy. It was adapted as Blood from the Mummy's Tomb by Hammer in 1971, and then again in the U.S. in 1980 as The Awakening, starring Charlton Heston.

7 It is not possible to state with any certainty how many of these stories (and others) were known to the Hollywood screenwriters. However, there is little doubt that there are many plot points in common, and the popularity of Conan Doyle would indicate 
that his stories are likely to have been known, at least by John L. Balderston, the final scenarist on the 1932 film. Victorian and Edwardian fiction, along with the silent movies considered next, do show that The Mummy movie made in 1932 did not spring solely from the screenwriters' own imaginations.

8 The early years of cinema produced over forty films with an Egyptian theme before the definitive mummy film of 1932. These began in the earliest days, in 1899, as French fantasy film pioneer Georges Méliès produced Cleopatra, showing her being raised from the dead. The last film before Freund's 1932 classic was a Disney 'Silly Symphony' cartoon called Egyptian Melodies, in which a spider investigates tunnels beneath a sphinx and discovers dancing mummies and ranks of marching hieroglyphics. ${ }^{i}$ Between these two there were films of varying running times, dividing into either comedies or dramas. Several are derived from the fictions discussed earlier; however, it is interesting to note that the discovery of the tomb of Tut-Ankh-Amen, and the intense media interest in it, did not lead to more films. In fact, of the forty or so films of this era only five were produced from 1923 onwards. Many of the plots, especially the comedies, have little in common with the mummy films under discussion here; especially popular are instances of people dressing up as mummies in order to play jokes or to fool and frighten other characters. As with the literature, many of the silent movies involve the revivification of female mummies, and the reincarnated lovers are male, which is the opposite of nearly all the films that were made later.

9 The storylines from the silent films that have an influence on the major mummy films can be divided into four categories:

- Curses - on either defilers of tombs or on artefacts removed from tombs.

- Fluids/elixirs - used to bring mummies back to life.

- Reviving mummies - usually females, either by use of a fluid or by electricity.

- Reincarnation - revived mummies find their former lovers reincarnated in modern people.

10 Some of the films can be seen as adaptations of some of the literature, such as The Beetle (Dir: Alexander Butler, UK, 1919), but the majority have taken specific ideas from the literature and used them for dramatic effect.

11 Curse: The curse on a tomb or its contents, or made against those who defile the sanctity of the grave appears in seven of the silent films. Stoker's Jewel of the Seven Stars features artefacts taken from a tomb, and in particular the ring of the title. The earliest film on this theme, made in the UK in 1912, is one of the longest and it features Napoleon Bonaparte in his invasion of Egypt. A cursed scarab ring is stolen from a mummy, and successive owners of it are killed. The curse is lifted when an Egyptologist returns it to the mummy, whose eyes glow in triumph. Two years later, the Edison Company made two attempts at a similar story. One, called Naidra, The Dream Worker, was a three-reel drama in which a man steals a necklace from a mummy and then finds that he is unable to dispose of it. The other version was called The Necklace of Rameses (Dir: Charles Brabin, USA, 1914), where a curse prevents a jewel thief from peddling a necklace he has stolen from the mummy of Rameses' daughter. In 1918-19 there was a fifteen chapter serial that involved a cursed stolen gem. Following the opening of the tomb of Tut-Ankh-Amen and the press stories about a curse, there were, strangely, only two films that attempted a dramatization. The first, King Tut-Ankh-Amen's Eighth Wife (Dir: Andrew Remo, USA, 1923), was a drama about a curse on those who violated the tomb of the Pharaoh. Three years later Cecil B. DeMille produced Made for Love (Dir: Paul Sloane, USA, 1926) where, apparently, a man is killed by the curse on an Egyptian 
tomb. Garrett Fort who later worked on Dracula, Frankenstein and The Invisible Man scripted this film.

Fluids/Elixirs: A fluid that can revive the dead appears in three films between 1911 and 1916. A chemical process features in Conan Doyle's Ring of Thoth; such a method does not reappear until the first Universal sequel to The Mummy, The Mummy's Hand (Dir: Christy Cabanne, USA, 1940). Here the fluid is made from the fictional tana leaves, of which there is only a vague reference in Conan Doyle or the silent movies. They were the invention of screenwriters, who claimed in publicity that the leaves were used as part of the embalming process (Brunas, Brunas and Weaver 234). In one of the early films, The Mummy (Dir: A. E. Colby, UK, 1911), the elixir may not have been used on a mummy at all - in the film the scientist's assistant impersonates a mummy as part of a plan to marry the professor's daughter. In Too Much Elixir of Life (Dir: Bruce Mitchell, USA, 1915), a professor believes that his elixir has restored life to an ancient mummy. A comedy short of a year later, Elixir of Life (Dir: Allen Curtis, USA, 1916) has a potion that not only returns a mummy to life but also sausages back into dogs.

13 Reviving Mummies: Reviving mummies is the oldest storyline from mummy fiction. Some of the silent films use electrical apparatus as described by Jane Webb or Poe, or use an elixir. Only Conan Doyle employed a supernatural means to revive a mummy in Lot No. 249 , and it is not clear from the descriptions of some of the silent films whether such a method was used. The films do share with the fiction the idea that most of the revived mummies are female, which rarely happens in later films (only in The Mummy's Curse (Dir: Leslie Goodwins, USA, 1944) do we see a female mummy revive, though no external agency is involved). One film that definitely did have a male mummy revived was produced in France in 1909, and King Rameses in this film was probably restored to life through chemical means.

14 Reincarnation: Closely allied in popular consciousness with revived mummies is the notion of reincarnation, usually of a lover. This idea has its literary roots in Haggard's Smith and the Pharaohs, where the modern Egyptologist discovers that the reason for his fascination for an Egyptian princess is that he is her reincarnated lover. An early adaptation of Gautier's The Mummy's Foot, made in France in 1910, ends with the character Lord Evandale, who has dreamt that he loved an Egyptian princess, waking up to meet and marry a woman who looks just like her. The first film to feature a reincarnated lover was When Soul Meets Soul (Dir: J. Farrell McDonald, USA, 1912), and two years later there are two reincarnated lovers who actually restore life to a 3,000year-old princess in Through the Centuries (Dir: Fred W. Huntley, USA, 1914). The idea of rival lovers can be found in Conan Doyle's Ring of Thoth, though this story and Huntley's film are very different. In all there are six silent films that feature reincarnations, but it is only the 1917 drama The Undying Flame (Dir: Maurice Tourneur, USA) that resembles the 1932 Universal picture in that it has an ancient Egyptian reincarnated in the body of an English girl.

15 The genesis of ideas that informed Freund's The Mummy can be seen in some of these silent films. The degree to which these films influenced the writers of the classic 1932 film can only be a matter of speculation. Some of the silent film ideas found their way into earlier drafts of the 1932 film, but were discarded.

16 The background to the making of The Mummy in 1932, indeed the background to American society at that time, was the Great Depression. The great inter-war slump is usually dated from 29 October 1929, when the New York stock market crashed; however 
the collapse came against the background of an already declining and fragile world economy (Overy 264). The film industry was not unaffected, even though those stars and executives at the top earned phenomenal salaries. The dollar's buying power was high - admission at some local movie theatres was as low as 5 cents - but many people had little to spend on anything but necessities (Thompson and Bordwell 213). Despite this, attendances stayed high and would climb throughout the 1930s and peak in the boom years of wartime. One of the most popular genres during the first half of the Great Depression was the "horror" film, although that term was yet to be coined. What we recognize today as the horror film was described as a "thriller" in the silent days and the early years of sound. It was in Europe that the stylistic elements for horror were laid down. The influence of The Cabinet of Dr. Caligari (Dir: Robert Wiene, Germany, 1919), The Golem (Dir: Paul Wegener, Germany, 1920) and Nosferatu (Dir: F. W. Murnau, Germany, 1922) is strong on the Universal classics of 1931 to 1936. Son of Frankenstein (Dir: Rowland V. Lee, 1939), re-launching the genre for the studio, took these elements and pushed them almost into parody - little surprise, then that this film forms the basis for Mel Brooks' 1974 comedy pastiche. Many of the German filmmakers and technicians found their way to Hollywood, and some to Universal. For example one was Paul Leni, who directed some influential silent thrillers, including the Cat and the Canary at Universal in 1927.

Universal's origins can be traced back to 1906 when Carl Laemmle gave up his post as a bookkeeper and used his savings to buy and operate a nickelodeon in Chicago. Universal were one of eight large companies who dominated the industry, though they were not one of the "majors." To be a Major, a company had to be vertically integrated, owning a theatre chain and having an international distribution operation (Thompson and Bordwell 214). The five majors, Paramount, MGM, $20^{\text {th }}$ Century-Fox, Warner Brothers and RKO, dominated the industry not through their control of production but through their ownership of the most desirable and profitable movie theatres. Although it was the largest of the other three (Columbia and United Artists being the other two), and it had an extensive distribution system, Universal had constant money problems (Thompson and Bordwell 216). Apart from the problems caused by the depression, Laemmle "imported shiploads of relatives and friends from Germany and employed them in dozens of diverse positions" (Brunas, Brunas and Weaver 2). Net losses exceeded profits on a regular basis, for example, for the nine months ending 31 October 1932 , while The Mummy was in production, there was a net loss of $\$ 759,646$, a figure greater than the profit for the whole of the year of 1931 (Brunas, Brunas and Weaver 2). That was the year of the great success of Dracula (Dir: Tod Browning), the film that initiated the horror cycle.

18 In the silent days, Universal had produced three of the best known "thrillers." Apart from The Cat and the Canary mentioned above, they also produced The Hunchback of Notre Dame (Dir: Wallace Worsley, 1923) and The Phantom of the Opera (Dir: Rupert Julian, 1925, re-released in 1929 with some sound effects and music added), which both starred Lon Chaney. Since the stage success of Dracula, the Studio had been in negotiation for the property, with Chaney in mind for the title role. Although Laemmle was against it, he had given the running of the studio over to his son, Carl Jr., who completed the deal and put the film into production. Despite its unparalleled box office performance, Universal remained in deep financial difficulties. The reaction to a major hit was not talk of a sequel as would happen today, but a follow-up of a similar nature was required for the studio to remain solvent (Brunas, Brunas and Weaver 21). As Andrew Tudor puts 
it, "financially successful films encourage further variations on their proven themes, thus generating a broadly cyclical pattern of successes which then decline into variously unsuccessful repetitions of the initial formula" (Tudor 23). In the initial cycle of Universal horrors, 1931-36, repetition was minimal, but they did establish the formulas that were repeated in the second cycle from 1939-46. The follow up to Dracula, Frankenstein, was an even greater success, and Universal now looked for another success that would use its new star, Boris Karloff.

The unifying thread of un-dead beings can be seen again in the figure of the mummy. The preservation of the body as practised in ancient Egypt was boosted in the popular imagination with the discovery of Tut-Ankh-Amen in 1922. In an attempt to allow the archaeological work to carry on unhindered by the press hordes, The Times of London was made the exclusive agent, and everyone, including Egyptians, had to go through London for news. With nothing else to report on, the myriad of journalists resorted to gossip and stories of the squabbling between Carnarvon, Carter and the Egyptian authorities (Guran 2). In March 1923, a writer of popular occult novels, Jessica Amanda Salmonson, wrote to The New York Times, and claimed that she had a translation of an Arabic text found in the tomb that promised "Death comes on wings to he who enters the tomb of a Pharaoh." After some interest from the fact-starved press, the curse story would have died down immediately if Lord Carnarvon had not died shortly after (Guran 2).

Fantastic story built on fantastic story. Conan Doyle, well known for his belief in the occult, announced to the world that a 'Pharaoh's curse' could indeed have caused Carnarvon's death (Hoving 226-27). This kind of sensationalism - reporting of fiction as fact - caused near hysteria: hundreds of people in England packed up and shipped to confused members of the British Museum staff every scrap of Egyptian antiquity that they had in their houses. Several American politicians went so far as to call for an investigation of mummies in various museums to determine whether or not these possessed the same medical dangers as those thought to be apparent in the tomb of Tut-Ankh-Amen (Hoving 228-29). Little attempt was made to establish any facts, or to ask questions - for instance, why was Howard Carter unaffected by the curse? Surely he, of all the defilers, would have been top of the list for retribution. The curse lived on, and talk of it was revived when the treasures from the tomb were on a world tour in the 1970s (Guran 2).

21 One of the reporters present at the opening of the tomb was John L. Balderston. After the Great War, Balderston was based in London as a correspondent for the New York World, and he was assigned to report on the discovery of Tut-Ankh-Amen (Guran 2). When Universal decided to use the mummy theme for their next supernatural thriller, they had a man on the payroll that had knowledge of and insight into ancient Egypt. However, the writing assignment went elsewhere, and when it did end up with Balderston, he was influenced by more immediate stories than those he may have written as a correspondent in Egypt. Carl Laemmle, Jr, the producer of the original horror cycle, conceived the idea of making a film loosely based around the discovery of Tut-Ank-Amen, and the alleged curse that accompanied it. Shrewdly, Laemmle also knew that such a story would not cost the studio any money for the story rights as it was in the public domain (Dyson 25). He assigned Nina Wilcox Putnam, a novelist, and Richard Schayer, head of the scenario department at Universal, to come up with a feasible story (Brunas, Brunas and Weaver 50). 
story, entitled Cagliostro, was about an ancient Egyptian who keeps himself alive by injecting nitrates, and who revenges himself through the centuries on women who resemble his unfaithful lover. The writers knew their Conan Doyle, but also they knew something of the real Cagliostro, an eighteenth century Italian who passed himself off as an alchemist and a hypnotist. He conducted séances and became a fashionable figure in aristocratic circles in France. Laemmle liked the story well enough to announce it as Karloff's next appearance for Universal and appropriate pre-publicity was drawn up. The story was passed to Balderston to write the screenplay, and he had experience in this area of the 'thriller' as he had been involved in the stage adaptations of both Dracula and Frankenstein.

Balderston made many crucial changes to the Putnam/Schayer story, most notably providing a supernatural element (the mummy is revived by reading the Scroll of Thoth) rather than a scientific one for the main character's survival over the millennia, and moving the story from San Francisco to the more exotic Cairo (Brunas, Brunas and Weaver 51). Neither the Putnam/Schayer treatment nor the Balderston script used the curse. In the script and the film the curse on the box containing the Scroll is read out, but apart, perhaps, from the unfortunate Norton, who reanimates Im-Ho-Tep, none of the other defilers are punished for their sacrilege then or later. Although Sir Joseph Whemple is murdered by Im-Ho-Tep, it is for more practical reasons than a curse. Balderston had ditched the Cagliostro angle and had changed the title to Im-Ho-Tep by the time he submitted the script on September 12,1932, and, it has been argued, he also changed the movie to resemble Dracula. Brunas, Brunas and Weaver contend that it "wouldn't be an exaggeration to call The Mummy a disguised remake of the Lugosi picture" (Brunas, Brunas and Weaver 52). There are many points of similarity in the two films as shown in the table below: ${ }^{i i}$

\begin{tabular}{|c|c|}
\hline Dracula & The Mummy \\
\hline Undead being & Undead being \\
\hline Hypnotic powers & Hypnotic powers \\
\hline Renfield as slave & Nubian as slave \\
\hline Film starts in ancestral homeland & Film starts in ancestral homeland \\
\hline Move to city setting (London) & $\begin{array}{l}\text { Move to city setting } \\
\text { (Cairo) }\end{array}$ \\
\hline Lives in house echoing origin in homeland & Lives in house echoing origin in homeland \\
\hline Young woman at centre of struggle (Mina) & Young woman at centre of struggle (Helen) \\
\hline $\begin{array}{l}\text { Confronted by knowledgeable expert (played by } \\
\text { van Sloan) }\end{array}$ & $\begin{array}{l}\text { Confronted by knowledgeable expert (played by } \\
\text { van Sloan) }\end{array}$ \\
\hline Ineffective fiancé (played by Manners) & Ineffective fiancé (played by Manners) \\
\hline
\end{tabular}


They track him to lair at the end

They track him to lair at the end

In keeping with genre theory, this can be seen as a prime example of repeating situations to meet audience expectations. There are two major twists that make it different. The heroine, Helen, is the reincarnated lover of Im-Ho-Tep, and is therefore much more than just a victim, and at the end the "heroes" do not destroy the monster. Because the heroine is in touch with her former incarnation, she is able to call on the power of the ancient Gods to save her from Im-Ho-Tep's plans. Much more was made of the reincarnation theme in Balderston's script. Scenes were filmed showing Helen in different guises throughout history, revealed to her in Im-Ho-Tep's magical pool. These scenes were later cut from the final release print. Zita Johann indicated that this was revenge for her insisting on being released from her contract. "It wasn't really nasty," she said, "they had to protect Karloff," suggesting that Laemmle felt her performance outshone the star (Mank 419). Karloff himself later said that the cuts were made for pacing reasons (Riley 31). Karloff's character also suffered from strange cutting decisions. For example, in the script, when he kills the museum guard, the guard has snatched the Scroll of Thoth, and when Karloff attempts to retrieve it, another guard arrives and he is forced to leave it. In the final film, most of this is left out, and it seems as if he has somehow just forgotten to take with him the most important object in the film.

The scroll was one of the things that Balderston introduced that not only added to the atmosphere, but also gave authenticity to the story. Thoth, depicted with the head of an ibis, was the wisest of the Egyptian gods, and he helped Isis work the ritual to bring Osiris back from the dead, and he is believed to be the author of the spells contained within the Book of the Dead. The names of the two central characters were taken from Egyptian history. Im-Ho-Tep was a multi-talented commoner in early Egypt, who was so revered that he later was regarded as a God. The name of the dead princess, Anck-esen-Amon, was the actual name of the wife of Tut-Ank-Amen, which would have been well known to Balderston, though probably not many others in Hollywood.

The film was written for Karloff, as is made clear in the character list in the script, and though most stills of the film available today show him as Im-Ho-Tep, he only appears in full mummy make-up for the first few minutes. For the rest of the film he portrays Ardath Bey, and his make-up is not so heavy. The audience would have recognized Karloff as the mummy when he re-appears ten years after his disappearance - helpfully he is framed in a doorway, suggesting Im-Ho-Tep in his sarcophagus. His dislike of being touched and his precise, slow movements suggest his fragility. When he murders the museum guard, he does so off-camera, so that the characterization is not compromised, as it would be if he were seen struggling with another character. It was Karloff's first talking role at Universal (he had spoken in his appearance as Fu Manchu at MGM), and it was still a sympathetic role, much like the Frankenstein monster. $\mathrm{He}$ may be a murderer, but he doesn't belong in the same category as such blatantly evil Karloff characters as the Oriental sadist Fu Manchu (The Mask of Fu Manchu, 1932) or his Satan-worshipping Hjalmar Poelzig (The Black Cat, 1934) (Brunas, Brunas and Weaver 55).

The film follows the script very closely. Karl Freund, in his first film as director, seemed loath to step outside what was written, and Balderston's script already included the 
fluid camera movements for which Freund was famous. In the production itself there were two notable innovations. The Mummy was the first Universal horror to have a musical score, although it only amounted to around twenty minutes in all. The music was the idea of Freund himself, and was composed by James Dietrich to Freund's precise instructions. Freund was not happy with Dietrich's compositions and used stock pieces from earlier Universal pictures. For the opening credits, after a few bars, the music plays a piece from Tchaikovsky's Swan Lake - the same piece that had opened Dracula and Murders in the Rue Morgue. The second innovation, not just for Universal but also for the film industry, was that the film pioneered the use of the process screen (also called back projection), whereby characters can be placed in any location in the world without having to transport them and the crew to the actual locale (Riley 12). A second camera crew was dispatched from Universal's Berlin office to Cairo, where they photographed the locations and also shots from moving vehicles. Back in Hollywood, the film was projected on to a screen from behind and the actors played in front of it. The camera and the projector were synchronized, and in the final film the illusion is given that the action is taking place in Cairo. The process is most familiar from shots of characters travelling in cars, and it is appropriate that the first time the process was seen in the cinema it was of such a scene. There is a publicity photograph of the process in action, however the scene shown, if shot, did not appear in the final film. Apart from synchronization, careful attention has to be given to the lighting of the live action, ensuring that it matches the luminosity of the back projection.

The final cost of the film was $\$ 196,000$, significantly less than Dracula or Frankenstein (Riley 31). This figure does not include the costs of publicity, which Universal used effectively to sell the picture to the public. Posters of different sizes displayed "Karloff the Uncanny," and in New York there was a giant electrical billboard over Times Square. The press book gave hints to exhibitors on how they could increase business, ranging from casket-shaped hangers for a few cents to elaborate speaking mummies who would answer questions in the foyer. Almost all the publicity gimmicks used Karloff in the full mummy makeup, which must have given the public the impression that this was how Karloff would appear throughout the whole film. In the later films, Universal would not need to be so misleading.

Literature on The Mummy is variable. Some books on the subject of horror films barely mention it (Ivan Butler's Horror in the Cinema does not mention it at all), while others deem it a peak in the horror/thriller genre. In his survey of Hollywood in the Thirties, John Baxter describes it as 'a fantasy almost without equal' (Baxter 76). William K. Everson described it as "the closest that Hollywood ever came to creating a poem out of horror" (Everson 93). A slow pace with no fast cutting creates the poetic atmosphere, and this is criticised by some modern authors. Jeremy Dyson feels that this pace makes it hard to appreciate today, although he does acknowledge the care and the skill with which the picture was crafted (Dyson 26). Two articles by female authors examine the film in a different way from the usual horror film commentator. Carol Siri Johnson puts forward the view that while the film is "ostensibly a reification of the colonial British hegemony, [it] displaces itself, and presents a subverted and subversive message" (Johnson 105). She goes on to say that the film presents the colonial archaeologists never questioning "their right to excavate and loot the remains of an ancient civilization - there is a clear assumption that they are a superior culture, and, since superior, should rule" (Johnson 108). However, she sees that the film subverts this by showing that male and British standards are powerless against "the (sexualized) 
concept "Egypt". The mummy is stronger than the British empire" (Johnson 108). Also rather than being the standard man-save-woman horror scheme, the men are shown to be powerless. The hero, Frank, cannot save Helen; although he and Dr Muller arrive in time, they can do nothing. Helen's appeal to the statue of Isis sees the goddess raise an arm holding an Ankh and Ardath Bey crumbles to dust. "The Ankh is the Egyptian symbol of life, a circle with a cross, the contemporary symbol for woman" (Johnson 112). Another female writer disputes this interpretation of the film as empowered womanhood. Caroline T. Schroeder argues that "Isis represents the triumph of a submissive construction of femininity, in that Isis' actions serve to position Helen back to her "traditional" submissive position as beloved and wife" (Schroeder 4). Schroeder interprets the film as enforcing the colonial superiority, and it does this through the character of Helen. Through her mixed parentage (English-Egyptian), she symbolizes the struggle between the Orient and the West, and the threat posed to the rational world. The fact that the ancient Egyptian goddess saves "Helen herself from herself" could be seen as subversive, but in fact the Egyptians "are finally subjected to British rationality and sensibility through their own complicity in the colonial project" (Schroeder 2). Not all commentators are convinced by this triumph of colonialism. Annette Kuhn describes the ending as failing "to deliver a complete resolution, and the 'victory' of the powers of western enlightenment remains somewhat unconvincing" (Kuhn 90).

30 Egypt had declared its independence in 1922, and the ownership of relics is mentioned in the film, when Frank feels it unjust that the Cairo Museum receives the finds of his expedition. Further racist references by Frank are in Balderston's script, but they were either not filmed or did not make the final cut. In the original film, it is the westerners who 'invade' Egypt, and stir up powers they cannot understand. Later films reverse this concept, the mummy comes to the west, and the populace must pull together to defeat the menace in undisguised wartime propaganda.

The Mummy remains a unique film, as much romance as thriller (Halliwell 211).

\section{BIBLIOGRAPHY}

Works Cited

Baxter, John. Hollywood in the Thirties. New York: A.S. Barnes, 1968.

Brunas, Michael, John Brunas, and Tom Weaver. Universal Horrors: The Studio's Classic Films, 1931-1946. Jefferson, NC: McFarland, 1990.

Craig, J. Robert and B.R. Smith. "Tracking the Sands of Time: Origin Stories in the Mummy Films." Journal of Evolutionary Psychology. August 2003: 172-80.

Delahoyde, Michael. “The Curse of the Mummy's Text.” http://www.wsu.edu/ delahoyd/ mummy.article.html [accessed 13 February 2005].

Dyson, Jeremy. Bright Darkness: The Lost Art of the Supernatural Horror Film. London: Cassell, 1997. 
Everson, William K. Classics of the Horror Film. Seacaucus, N.J.: Citadel Press, 1974.

Guran, Paula. "Return of the Mummy: Part Two - Curses!" http://www.darkecho.com/darkecho/ horroronline/mummy2.html [accessed 11 February 2005].

Halliwell, Leslie. The Dead That Walk. London: Paladin, 1988.

Hoving, Thomas. Tutankhamun: The Untold Story. London: BCA, 1979.

Johnson, Carol Siri. “The Limbs of Osiris: Reed's Mumbo Jumbo and Hollywood's The Mummy.” MELUS 17 (1991-92): 105-15.

Jones, Stephen. The Essential Monster Movie Guide. London: Titan Books, 1999.

Kuhn, Annette. An Everyday Magic: Cinema and Cultural Memory. London: I.B. Tauris, 2002.

Mank, Gregory. “The Mummy Revisited.” Films In Review 35 (1984): 414-21.

Newman, Kim (ed.). The BFI Companion to Horror. London: British Film Institute, 1996.

Overy, Richard (ed.). The Times History of the World. London: Times Books, 1999; repr. 2000.

Pearson, Richard. "Archaeology and Gothic Desire: Vitality Beyond the Grave in H. Rider Haggard's Ancient Egypt." Victorian Gothic: Literary and Cultural Manifestations in the Nineteenth Century. Ed. Ruth Robins and Julian Wolfreys. Basingstoke: Palgrave Publishers, 2000.

Riley, Philip J. (ed.) “The Mummy”: The Original 1932 Shooting Script. Atlantic City: MagicImage Filmbooks, 1989.

Schroeder, Caroline T. "Ancient Egypt on the Silver Screen: Modern Anxieties about Race, Ethnicity and Religion.” Journal of Religion and Film 7 (2003)._www.unomaha.edu/jrf/Vol7No2/ ancientegypt.htm.

Thompson, Kristin and David Bordwell. Film History: An Introduction. $2^{\text {nd }}$ Edition. New York: McGraw-Hill, 2003.

Tudor, Andrew, Monsters and Mad Scientists: A Cultural History of the Horror Movie. Oxford: Basil Blackwell, 1989.

Filmography (Films mentioned in the article in chronological order)

Mummy Films

1899 Cleopatre. Dir. Georges Méliès. Georges Méliès. Star Film.

1909 The Mummy of King Ramses. Dir. Gerard Bourgeois. Lux.

1910 The Romance of the Mummy. Pathe.

1911 The Mummy. Dir. A.E. Colby. Pathe-Britannia.

1912 When Soul Meets Soul. Dir. J. Farrell McDonald. Francis X. Bushman, Dolores Casinelli, Fred Wolf. Essanay.

1914 Naidra, The Dream Worker. Edison.

Necklace of Rameses. Dir. Charles Brabin. Robert Brower, Gertrude Braun, Marc McDermott. Edison Film Company.

Through the Centuries. Dir. Fred W. Huntley. Harold Lockwood, Mabel van Buren, Henry W. Otto. Selig Polyscope Company.

1915 Much Elixir of Life. Dir. Bruce Mitchell. Alhambra.

1916 Elixir of Life. Dir. Allen Curtis. William Franey, Gale Henry, Lillian Peacock. Joker/Universal. 
1917 The Undying Flame. Dir. Maurice Tourneur. Olga Petrova, Mahlon Hamilton, Edward Mordant. Lasky/Paramount.

1919 The Beetle. Dir. Alexander Butler. Leal Douglas, Fred Morgan, Maudie Dunham. Barker.

1923 King Tut-Ankh-Amen's Eighth Wife. Dir. Andrew Remo. Max Cohen.

1926 Made for Love. Dir. Paul Sloane. Leatrice Joy, Edmund Burns, Ethel Wales. Cinema Corporation of America.

1931 Egyptian Melodies. Dir. Wilfred Jackson. Disney/Columbia.

1932 The Mummy. Dir. Karl Freund. Boris Karloff, Zita Johann, Edward van Sloan. Universal.

1940 The Mummy's Hand. Dir. Christy Cabanne. Dick Foran, Peggy Moran, Cecil Kellaway. Universal.

1944 The Mummy's Curse. Dir. Leslie Goodwins. Lon Chaney, Peter Coe, Virginia Christine. Universal.

1971 Blood from the Mummy's Tomb. Dir. Seth Holt. Andrew Keir, Valerie Leon, James Villiers. Hammer/MGM-EMI.

1980 The Awakening. Dir. Mike Newell. Charlton Heston, Susannah York, Jill Townsend. EMI/Orion. Other Films

1919 The Cabinet of Dr. Caligari. Dir. Robert Wiene. Werner Krauss, Conrad Veidt, Lil Dagover. Decla-Bioscop.

1920 The Golem. Dir. Paul Wegener, Carl Boese. Paul Wegener, Lyda Salmonova, Ernst Deutsch. Union.

1922 Nosferatu. Dir. F.W. Murnau. Max Schreck, Greta Schroeder, Gustav von Wangenheim. Prana. 1923 The Hunchback of Notre Dame. Dir. Wallace Worsley. Lon Chaney, Patsy Ruth Miller, Norman Kerry. Universal.

1925 The Phantom of the Opera. Dir. Rupert Julian. Lon Chaney, Mary Philbin, Norman Kerry. Universal.

1927 The Cat and the Canary. Dir. Paul Leni. Laura La Plante, Creighton Hale, Forrest Stanley. Universal.

1931 Dracula. Dir. Tod Browning. Bela Lugosi, Helen Chandler, Edward van Sloan. Universal. 1931 Frankenstein. Dir. James Whale. Colin Clive, Boris Karloff, Mae Clarke. Universal.

1932 The Murders in the Rue Morgue. Dir. Robert Florey. Bela Lugosi, Sidney Fox, Leon Waycoff. Universal.

1932 The Mask of Fu Manchu. Dir. Charles Brabin. Boris Karloff, Myrna Loy, Lewis Stone. MGM. 1934 The Black Cat. Dir. Edgar G. Ulmer. Boris Karloff, Bela Lugosi, David Manners. Universal. 1939 Son of Frankenstein. Dir. Rowland V. Lee. Boris Karloff, Basil Rathbone, Bela Lugosi. Universal. 1974 Young Frankenstein. Dir. Mel Brooks. Gene Wilder, Peter Boyle, Marty Feldman. Twentieth Century Fox. 


\section{NOTES}

i. The film descriptions derive from Jones and from the Internet Movie Database <www.imdb.com>.

ii. Table compiled from text in Brunas, Brunas and Weaver 52-4.

\section{ABSTRACTS}

This article examines the literary and cinematic antecedents of a cinema icon, The Mummy, produced by Universal Pictures in 1932. It looks at the sources in Victorian and Edwardian literature to see if any of the ideas found their way into the film. Similarly, the silent cinema is surveyed to see if the 1932 film was a collection of previously filmed stories remoulded. The context of the Great Depression and its effects on Universal Studios will be shown to have a significant influence on the decision to make the film. The film itself and its publicity is discussed, followed by its reception at the time, and its significance to writers since.

\section{INDEX}

Keywords: Literature, culture, cinema, Edgar Allan Poe, Mummy, Hollywood, Egypt, Universal Pictures, Frankenstein, Dracula, Orientalism, Archaeology, Horror, Genre., Carl Laemmle, Carl Laemmle Jr, John L. Balderston, Boris Karloff, Zita Johann, David Manners, Edward van Sloan, Charlton Heston, Im-Ho-Tep, Tutankhamun, Lord Caernavon, Howard Carter, Georges Méliès, Karl Freund, Lon Chaney, Rupert Julian, Paul Leni, James Dietrich, Wallace Worsley, Richard Schayer, Nina Wilcox Putnam, Jessica Amanda Salmonson, Arthur Conan Doyle, Theophile Gautier, Mary Shelley, H. Rider Haggard, Gaston Leroux, Jane Loudon Webb, Richard Marsh, Bram Stoker

\section{AUTHOR}

\section{RICHARD FREEMAN}

Richard Freeman 